Snežana Đekić1,

Vera Đorđević

Danilo Mašković ${ }^{3}$

University of Nish,

Faculty of Economics, Nish
SCIENTIFIC REVIEW ARTICLE doi:10.5937/ekonomika1602097D

Received: March 29, 2016 Accepted: May 13, 2016

\title{
QUANTITATIVE ANALYSIS OF MULTI-FUNCTIONALITY OF AGRARIAN AND RURAL DEVELOPMENT IN THE REPUBLIC OF SERBIA
}

\begin{abstract}
The objective of this paper is, primarily, to point to the possibility of quantification of indicators related to multifunctional agricultural and rural development and decision making on the basis of the ones. Quantitative indicators should indicate the achieved level of multifunctional agricultural development in the Republic of Serbia, starting from widely accepted principles of this development: economic, ecological and social ones. The core of multifunctional agricultural and rural development is actually sustainable development which takes into consideration interests of present and future generations. The state development policy in solving sustainable development problems is of great importance, and decisions would be more real if they rely on measureable indicators and adequate quantitative analysis. Composite indicators, very useful for trends identification and drawing attention to certain questions of interest, have a special place in this analysis.
\end{abstract}

Key words: multifunctional agriculture, multifunctional development dimensions, sustainable development, composite indicators.

JEL classification: $\mathrm{C} 10, \mathrm{O} 13$

\section{КВАНТИТАТИВНА АНАЛИЗА ДИМЕНЗИЈА МУЛТИФУНКЦИОНАЛНОСТИ АГРАРНОГ И РУРАЛНОГ РАЗВОЈА У РЕПУБЛИЦИ СРБИЈИ}

\begin{abstract}
Резиме
Циљ овог рада је, првенствено, да укаже на могућност квантифицирања показатеља везаних за мултифункичионални пољопривредни и рурални развој и доношење одлука на основу юих. Квантитативни показатељи треба да укажу на достигнути ниво мултифункционалног пољопривредног развоја у Републици Србији полазећи, пре свега, од општеприхваћених принщипа овог
\end{abstract}

\footnotetext{
${ }^{1}$ snezana.djekic@eknfak.ni.ac.rs

${ }^{2}$ vera.djordjevic@eknfak.ni.ac.rs

${ }^{3}$ danilo.maskovic@yahoo.com
} 
развоја: економски, еколошки и сочијални. У основи мултифункционалног пољопривредног и руралног развоја је одрживи развој који уважава интересе садашњих и будућих генерачија. Велики је значај развојне политике државе у решаваюу проблема везаних за одрживи развој, а одлуке би биле реалније уколико се ослањају на мерљиве показатеље и адекватну квантитативну анализу. Посебно место у овој анализи имају композитни индикатори, који су веома корисни за индетификовање трендова и усмеравање пажње на одређена питања од интереса.

Кључне речи: мултифункционална пољопривреда, димензије мултифункционалног развоја, одрживи развој, композитни показатељи

\section{Introduction}

The subject of this paper is multifunctional agriculture and rural development as the concept of multi-functionality as well as the method of achieving growing sustainability of non-market public property, in agriculture as well as in a rural community. The subject is also closely related with the research problem, primarily directed onto application of quantitative analyses of basic dimensions of multi-functionality of agrarian and rural development of the Republic of Serbia. This is the reason for carrying out the analysis of indicators of multifunctional agrarian and rural development in this paper, first from theoretical point of view and afterwards in practice.

The objective of the research is recognition of places the Republic of Serbia has in its environment regarding modern agrarian and rural development related to the concept of multi-functionality. To get the right picture of this problem, it is necessary to perceive the basic characteristics (advantages and disadvantages) of multifunctional agrarian and rural development.

Starting from the problem of researching, as well as its objective, the basic hypothesis of this paper is as follows: the Republic of Serbia is at the beginning of multifunctional agrarian and rural development.

The analysis of the agriculture multi-functionality problem requires applying of quantitative indicators such as composite indicators. The composite indicators are obtained by means of compilation or aggregation of a number of individual indicators organized within a clear theoretical model, clearly defining multi-dimensional phenomena as competition, sustainable development, economic structure etc. Advantages of the composite indicators become apparent especially in situations which require solutions concerning complex economic and social questions. Indicators facilitate imposing of public and political discussions at right time, making decisions and informing the public. The basic quality confirmation of a composite indicator lies in its capability to meet requirements and be accepted by users and scientific-expert practice. As the result of the quantitative analysis, there are conclusions concerning the observed problem. The correlative analysis was applied on the observed sample data (composite indexes) and adequate conclusions are drawn on the basis of the result of the applied analysis. 


\section{Multi-functionality and agricultural production systems}

The term multi-functionality appeared in political documents concerning developing concepts of agriculture and rural regions during the last decade. Conceptual interpretation of multi-functionality is rather heterogeneous, so, from theoretical point of view, it has not been properly systematized yet. The concept of multi-functionality promote the idea that the agricultural production system, besides its basic functions has numerous non-productive externalities related to both sustainable and rural development, as well as a substantial social-demographic component. (Bogdanov, 2005).

According to it, agriculture can be called multifunctional if besides food production it also provides other benefits, such as: safe food for population, appropriate rural life conditions and environment protection.

Agricultural production development is carried out with different intensity and has economic, ecological and social characteristic. Noticeable detachment from conventional agriculture took place in 1960s, which resulted in ignoring and neglecting of basic functions and activities in rural districts On the other hand, social recognition that these functions must be treated with care, increases. As a result, a few alternative systems of agricultural production were developed in the following decades, among which there is multifunctional agriculture as well (Figure 1).

Figure 1: Agriculture production systems

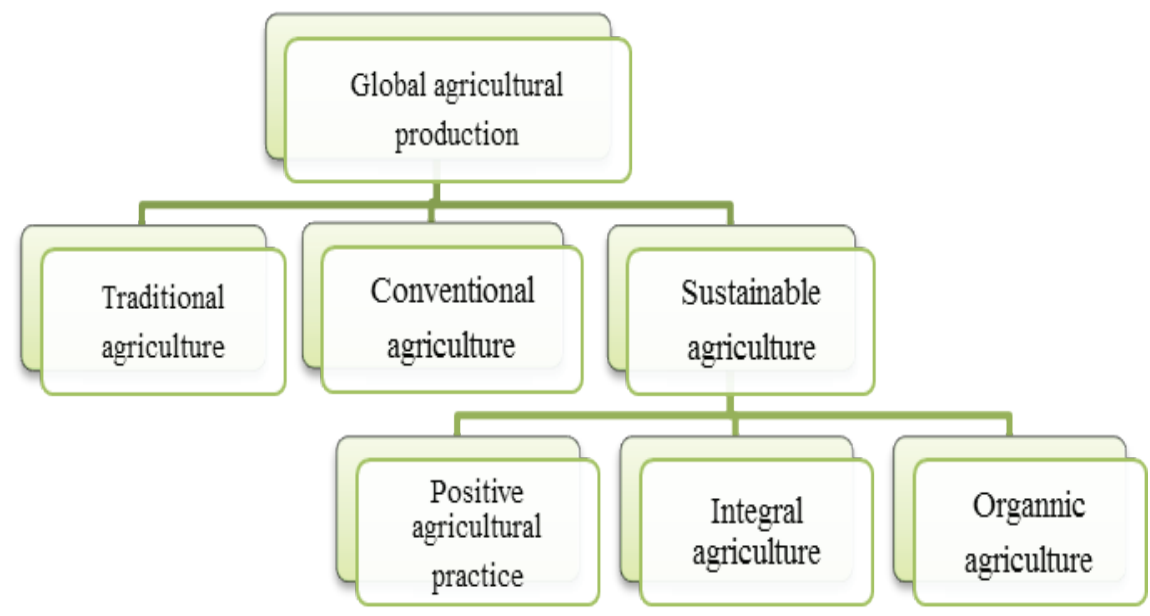

Source: Miltojevic, V.(2011) Culture as sustainable development dimension, Themes

Global agriculture production comprises traditional and conventional agriculture, as well as sustainable agriculture systems with the most frequently present: good agricultural practice, integral and organic ( biological, ecological) agriculture.

Traditional agricultural production is the one carried out on small farms .It prevails in rural districts of Serbia and mountainous regions.

Conventional agriculture has to provide maximum production, in respect to quantity and quality, with minimal expenses. The measures applied in conventional agricultural production led to degradation of resources with limited ability of selfregeneration, without which people cannot exist. 
Integral agriculture is actually improved conventional agriculture and the primary intention of this concept is reduced application of dangerous pesticides.

A group of economists united in The World Commission for Environment and Development (Brutland Commission) has introduced the term sustainable development into world's economy. This new concept has been introduced for the purpose of reconsidering the former development concept, based on constant increasing of growth and profit rate. Sustainable development is the development which meets requirements of the present time, without endangering capabilities of future generations to satisfy their own needs. The organic agriculture, which protects all existing resources, is an integral part of sustainable agriculture.

Limitations on above mentioned systems of agricultural production, as well as the experience gained through their application, with the addition of remarkable social ,economic and ecological pressures, created a new concept of multifunctional exploitation of land and multifunctional agriculture which would include all basic functions of rural districts ( environment protection, sustainability of natural and agrarian-historic ambient , climate control and global heating effects and health and welfare care). (Bogdanov, 2005).

Multifunctional agriculture is characteristic for European countries and it is famous for its lowest participation of agricultural population and relatively favorable ratio of land and population. Not only EU but also all other "friends of multifunctional agriculture" (Japan, Switzerland, Norway) recognized the fact that, besides food production, agriculture has the other non-market functions which should be respected.

\section{Basic dimensions of multifunctional agrarian and rural development}

The multifunctional model of agrarian and rural development is synchronized with natural environment and tends to preserve the environment in sustainable development. Serbia has to define the national (social, economic, ecological) priorities in its rural development and they must be directed by accepted models of extended environment, first of all EU. The basic objective is negative trends holding up (demographic and economic) as well as preserving of natural and cultural heritage of rural surrounding.

The concept of sustainable development appeared in 1980s and it is defined as " development meeting present problems without questioning the possibility of future generations to satisfy their needs" (the report of Brutland commission on environment and development). It is actually a new approach, known as "3 pillars model" comprising ecological, social and economic objectives (Figure 2). 
Figure 2: Sustainable development dimensions

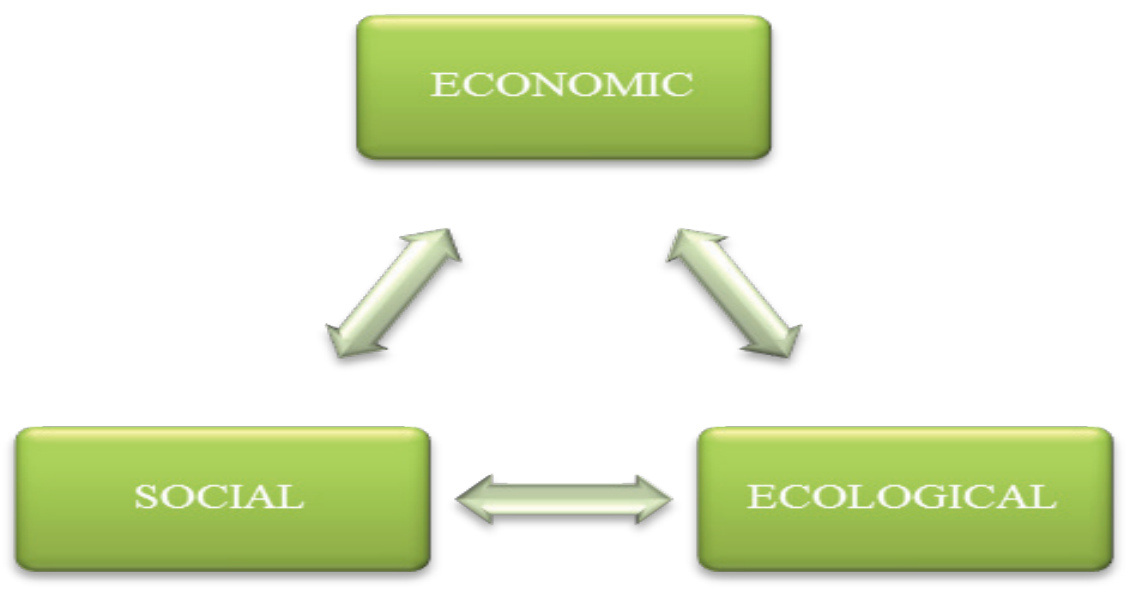

Source: Miltojevic, V (2011) culture as sustainable development dimension, Themes, 35(2)

A fundamental pillar which is the framework of sustainable development is an economic pillar; i.e.it is a principle of coordination of economic development with resources and production capacities. Disrespect of sustainability concept leads to inefficient economic development in terms of bigger and bigger dissipation of resources and energy. The economic dimension is observed through two fields: production and economic structure and consumption.(Miltojevic, V; 2011).

A social pillar refers to social relations, increasing of welfare of population, improving of the approach to basic health and educational services, satisfying of minimum standard of protection and human rights respect. It is followed through five fields: health, social justice, education, population, safety and dwelling.(Miltojevic, V; 2011).

An ecological pillar expresses concern for conservation and increasing of physical and biological resource basis of ecosystem. Ecological system includes elements of the environment that mankind use in activities processes and adjusts it to meet owen needs. On the other side, the men often produce a lot of unwanted products, which burden the ecosystem. (Mihajlovic D., Ilic B., Simonovic Z., 2013) It is observed through five fields: atmosphere, land, oceans (sees), waters and bio-diversity. (Miltojevic, V; 2011).

According to numerous authors, if there is a wish to reach sustainable development it is necessary to adjust four supports of sustainable development: economic, ecological, social and cultural. There are also authors who share opinion that sustainable development must not be reduced to three dimensions, but they also think that the fourth dimension does not comprise culture. They mentioned political or even institutional dimension as the fourth pillar of sustainable development.

The analysis of basic dimensions of sustainable development, which is the framework of multifunctional agricultural development, will be carried out by means of composite indicators. Generally speaking, an indicator is a quantitative or qualitative measure originating from numerous facts and it can reveal and indicate the direction of 
change in one field. The indicators are very useful for trends identification and drawing attention to certain questions of interest.

\section{Multi-functionality dimensions analysis}

For analysis of basic dimensions of multi-functionality, the countries of Southeast Europe, among which is Serbia, are observed. They make an entity in the Southeast of European continent. The percentage of rural population is considerable in the total and it is similar in all countries of the Southeast Europe. According to the data for 2008, 2010, 2012 and 2014 it can be concluded that most countries characterize decreasing of rural inhabitants' number every year. It is interesting that Greece has the smallest percentage of rurality (about 24\%), and Moldavia and Bosnia the biggest one (Table 1, Figure 3).

Table 1: Rural population (\% of the total)

\begin{tabular}{|l|c|c|c|c|}
\hline Country & 2008 & 2010 & 2012 & 2014 \\
\hline Albania & 50 & 48 & 46 & 44 \\
\hline Bosnia & 53 & 52 & 51 & 60 \\
\hline Bulgaria & 28 & 27 & 26 & 26 \\
\hline Croatia & 43 & 42 & 42 & 41 \\
\hline Macedonia & 41 & 41 & 41 & 43 \\
\hline Romania & 47 & 47 & 47 & 46 \\
\hline Serbia & 45 & 44 & 43 & 45 \\
\hline Moldavia & 55 & 53 & 52 & 55 \\
\hline Montenegro & 37 & 37 & 37 & 36 \\
\hline Turkey & 31 & 30 & 28 & 27 \\
\hline Greece & 24 & 24 & 23 & 22 \\
\hline
\end{tabular}

Source: http://data.worldbank.org/indicator/SP.RUR.TOTL.ZS

Figure 3: Rural population participation in the total by countries (in \%)

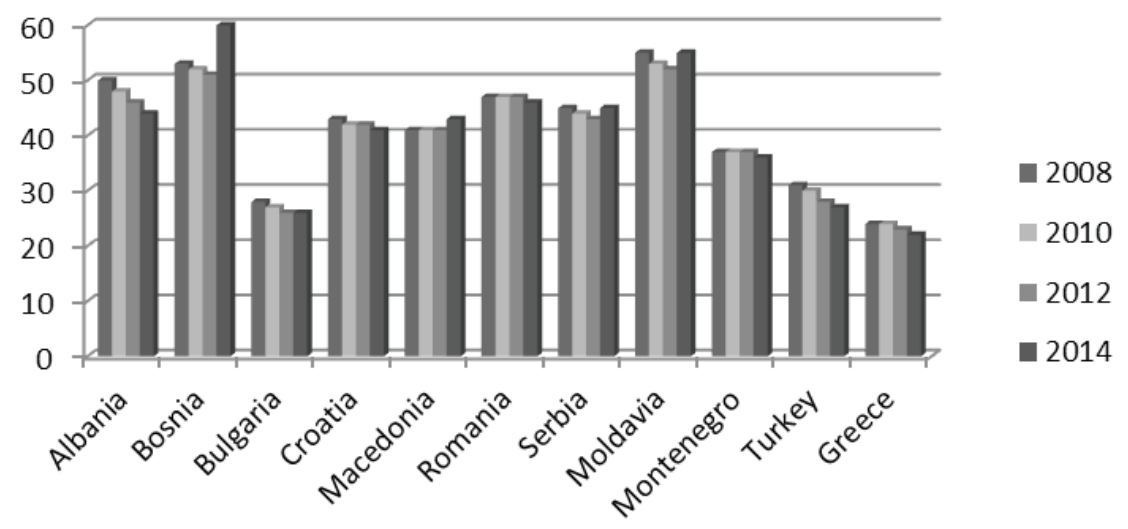


The countries of Southeast Europe (SEE) have been in the process of transition for last fifteen years Although institutional and structural reforms are the main challenge in the whole region, macroeconomic characteristics are noticeable in the region During 2004 and 2005 the countries of SEE experienced the biggest economic growth since the beginning of transitional changes, with similar tendencies in next years, although at slower rate. The participation of mining, industry, agriculture and forestry dominate economic structure, while the services sector is not so developed.

It is necessary to define the set of indicators of the development, for both monitoring of the achieved level of development, and creating of an appropriate strategy and the policy of multifunctional agrarian and rural development. Some of the most important indicators for monitoring of the achieved level of multi-functionality are: employment rate, expected lifetime, emission of poisonous gases etc. Besides these, there is also a composite indicator and it stands for an aggregate index which comprises individual indicators and corresponding weight coefficients that usually represent relative importance of each indicator. It measures multi -dimensional concepts which cannot be comprised by a single indicator. The composite indexes include indicators of economic, ecological, social and innovative dimension of multi-functionality. Each dimension of multi-functionality is equally important, but in some specific circumstances some of them are given priority.

Economic growth is in the focus of the economic dimension of multi-functionality, but with limitations imposed by natural conditions. In fact, this dimension implies effective usage of natural resources for economic growth ensuring. Besides the indicators such as consumption level, production, and trade, one of the significant indicators of economic dimension of multi-functionality is GNP per capita. Gross national product is the total value of end products and services manufactured in a country in a given period. Gross value added (GVA) is a part of GNP increased by taxes and reduced by subventions. In this case, GVA is observed as an economic dimension and Table 2 presents the data referring to GVA in agriculture (\% of GNP) for 2008, 2010, 2012 and 2014.

Table 2: Gross value added in agriculture (\% of GNP)

\begin{tabular}{|l|c|c|c|c|}
\hline Country & 2008 & 2010 & 2012 & 2014 \\
\hline Albania & 19.4 & 20.7 & 21.7 & 22.6 \\
\hline Bosnia & 9.1 & 8.4 & 7.7 & 7.6 \\
\hline Bulgaria & 7 & 49 & 53 & 53 \\
\hline Croatia & 5 & 49 & 45 & 43 \\
\hline Macedonia & 13.3 & 11.7 & 10.5 & 10.2 \\
\hline Romania & 6.6 & 6.3 & 5.3 & 5.4 \\
\hline Serbia & 10.3 & 10.2 & 9 & 9.7 \\
\hline Moldavia & 10.7 & 14.4 & 13.4 & 15 \\
\hline Montenegro & 9.3 & 9.2 & 8.9 & 10 \\
\hline Turkey & 8.5 & 9.5 & 8.8 & 8.0 \\
\hline Greece & 3.2 & 3.3 & 3.7 & 3.8 \\
\hline
\end{tabular}

Source: Beyond GDP, http://www.beyond-gdp.eu/index.html

For environment policy creators, identification of the most significant problems of the natural resources and environment field, is of crucial importance as it can help 
them direct the actions to their elimination and lessening. Besides that, the importance of establishing environment indicators is at the same time the possibility of making comparison with indicators of other countries and establishing the achieved level of ecological performances. EPI index is one of the indexes showing the countries to what extent they have progressed in fulfilling targets concerning environment policy (this methodology has been developed by the World Economic Forum, Yale University and Columbia University). The Table 3 shows tabular presentation of EPI index for the countries of South-East Europe for 2008, 2010, 2012 and 2014.

Table 3: EPI by the countries

\begin{tabular}{|l|c|c|c|c|}
\hline Country & 2008 & 2010 & 2012 & 2014 \\
\hline Albania & 84 & 71.4 & 65.86 & 54.73 \\
\hline Bosnia & 79.7 & 62.5 & 36.76 & 45.79 \\
\hline Bulgaria & 78.5 & 55.9 & 56.28 & 64.01 \\
\hline Croatia & 84.6 & 68.7 & 64.16 & 62.23 \\
\hline Macedonia & 75.1 & 60.6 & 46.96 & 50.41 \\
\hline Romania & 71.9 & 67 & 48.34 & 50.52 \\
\hline Serbia & - & 69.4 & 46.14 & 69.13 \\
\hline Moldavia & 70.7 & 58.8 & 45.21 & 53.36 \\
\hline Montenegro & - & 69.4 & 46.14 & 55.52 \\
\hline Turkey & 75.9 & 60.4 & 44.8 & 54.91 \\
\hline Greece & 80.2 & 60.9 & 60.04 & 73.28 \\
\hline
\end{tabular}

Source: 2014 Environmental Performance Index and Pilot Trend Environmental Performance Index, Yale University (Yale Center for Environmental Law and Policy - YCELP), Columbia University (Center for International Earth Science Information Network - CIESIN) in collaboration with World Economic Forum, 2014. Available at http: www.epi/yale.edu/downloads

SSI Index (Sustainable Society Index) has been chosen for the analysis of the social dimension of sustainable development in this paper. The main goal of this index is stimulating and helping nations (countries) in their development through sustainability on their way towards multi-functionality.SSI is estimated on the basis of 21 indicators classified into three welfare categories (ecological ,human and economic welfare). The Table 4 presents SSI values for the countries of Southeast Europe for the observed period.

Table 4: SSI by countries

\begin{tabular}{|l|c|c|c|c|}
\hline Country & 2008 & 2010 & 2012 & 2014 \\
\hline Albania & 6.26 & 6.5 & 5.76 & 5.64 \\
\hline Bosnia & 5.96 & 5.83 & 3.92 & 4.75 \\
\hline Bulgaria & 5.84 & 6.3 & 5.13 & 5.93 \\
\hline Croatia & 5.97 & 6.53 & 5.55 & 6.05 \\
\hline Macedonia & 5.76 & 6.07 & 4.94 & 5.22 \\
\hline Romania & 6.09 & 6.7 & 5.48 & 6.47 \\
\hline Serbia & 5.53 & 6.39 & 4.5 & 5.24 \\
\hline Moldavia & 6.21 & 6.5 & 4.87 & 5.69 \\
\hline Montenegro & 5.58 & 6.47 & 5.6 & 5.86 \\
\hline Turkey & 6 & 6.07 & 4.77 & 5.53 \\
\hline Greece & 5.75 & 6.13 & 4.32 & 4.94 \\
\hline
\end{tabular}

Source: Sustainable Society Foundation

The innovation index has been chosen for innovation analysis in this paper. Technological innovations, especially important for continuous growth of highly 
developed world economies, represent one of the competition pillars. Less developed countries can still achieve big productivity growth owing to improvement of institutions, infrastructure and similar fields, but it is no longer enough for economies led by innovations Long-term growth in the living standard and competition strengthening could be improved only by means of technological innovations adopting and applying. This implies creating of environment which is completely oriented towards innovative activities and has support of both private and public sector. The Table 5 shows innovativeness indexes for the countries of East Europe.

Table 5: Innovativeness index

\begin{tabular}{|l|c|c|c|c|}
\hline Country & 2008 & 2010 & 2012 & 2014 \\
\hline Albania & 2.22 & 2.57 & 2.58 & 2.7 \\
\hline Bosnia & 2.37 & 2.59 & 2.84 & 2.8 \\
\hline Bulgaria & 2.91 & 2.91 & 2.94 & 2.9 \\
\hline Croatia & 3.41 & 3.08 & 3.09 & 3.1 \\
\hline Macedonia & 2.86 & 2.88 & 2.81 & 3.3 \\
\hline Romania & 3.14 & 2.94 & 2.91 & 3.3 \\
\hline Serbia & 3.09 & 2.93 & 2.9 & 2.9 \\
\hline Moldavia & 2.49 & 2.44 & 2.40 & 2.5 \\
\hline Montenegro & 2.96 & 3.48 & 3.39 & 3.4 \\
\hline Turkey & 3.16 & 3.10 & 3.15 & 3.4 \\
\hline Greece & 3.18 & 3.00 & 2.98 & 3.2 \\
\hline
\end{tabular}

Source: http://www.weforum.org/issues/competitiFveness-O/gci2014-data-platform/

In order to examine matching i.e. intensity (strength) of the connection of all four indicators simultaneously, the coefficient of multiple linear correlation for each observed year has been calculated. Prior to the coefficient calculating, the analysis of available data was carried out and an appropriate indicator of interdependence of observed indicators was chosen. Interpretation of obtained indicators is carried out to Cohen (Cohen,1988).

The multiple linear correlation coefficient for $\mathbf{2 0 0 8}$ is 0,790 (between 0,5 and 1,0) which suggests that there is a substantial correlative connection of practical importance between observed indicators. As this coefficient shows only the matching degree but not the direction, it is necessary to calculate so called partial correlations.

The partial correlation coefficient shows the degree (intensity) of the connection between two observed indicators without taking into account the influence of the others as well as their matching direction. The Table 6 contains the value of a coefficient of correlation between dimensions of multifunctional rural development in 2008 . The calculated correlation coefficients show that the degree of matching between innovativeness and GVA $(-0,737)$ is substantial but between innovativeness and SSI $(-0,472)$ medium. It is interesting that these coefficients demonstrate inverse connection between observed indicators. The explanation can be found in the analysis of available data. Innovativeness as well as a social component in the observed year, did not have the expected influence on GVA, i.e. these two indicators point to insufficient investments which affected inverse connection. Taking into consideration $\mathrm{p}$-value for interdependency between the innovativeness index and GVA, it can be concluded that the calculated coefficient cannot be accepted as a valid indicator. Concerning interdependency between INOV and SSI, the fact that bigger investments and innovations have negative influence on the social component, can be accepted. The other coefficients are irrelevant and they will not be the subject of the analysis. 
Table 6: Value of the coefficient of correlation between dimensions of multi-functional rural development in 2008

\begin{tabular}{|c|c|c|c|c|c|}
\hline & & GVA2008 & EPI2008 & SSI2008 & INOV2008 \\
\hline \multirow[t]{2}{*}{ GVA2008 } & $\begin{array}{l}\text { Pirson's } \\
\text { correlation } \\
\text { coefficient }\end{array}$ & 1 & & & \\
\hline & p-value & & & & \\
\hline \multirow[t]{2}{*}{ EPI2008 } & $\begin{array}{c}\text { Pirson's } \\
\text { correlation } \\
\text { coefficient }\end{array}$ & 0.071 & 1 & & \\
\hline & $\mathrm{p}$-value & 0.856 & & & \\
\hline \multirow[t]{2}{*}{ SSI2008 } & $\begin{array}{c}\text { Pirson's } \\
\text { correlation } \\
\text { coefficient }\end{array}$ & 0.317 & -0.105 & 1 & \\
\hline & $\mathrm{p}$-value & 0.342 & 0.788 & & \\
\hline \multirow[t]{2}{*}{ INOV2008 } & $\begin{array}{c}\text { Pirson's } \\
\text { correlation } \\
\text { coefficient }\end{array}$ & $-0.737 *$ & 0.003 & -0.472 & 1 \\
\hline & $\mathrm{p}$-value & 0.010 & 0.994 & 0.142 & \\
\hline
\end{tabular}

*The correlation is statistically significant on the level of significance 0.05.

Source: The author's own calculation

The multiple linear correlation coefficient for $\mathbf{2 0 1 0}$ is 0,679 (between 0,5 and 1,0) which suggests that the interdependence between all four indicators is substantial and of practical importance. Analyzing of obtained partial correlation coefficients leads to the conclusion that there is still substantial correlation degree between INOV and GVA .It is actually an inverse connection between observed indicators $(-0,516)$. There is a substantial matching degree between SSI and EPI- it is a direct $(0,509)$ connection. One should be cautious with the interpretation of the obtained indicators, as they are close to the lower limit for the intensity of the connection considered as a substantial one.

Table 7: Values of coefficient of correlation between dimensions of multi-functional rural development in 2010

\begin{tabular}{|c|c|c|c|c|c|}
\hline & & GVA2010 & EPI2010 & SSI2010 & INOV2010 \\
\hline \multirow{2}{*}{ GVA2010 } & $\begin{array}{c}\text { Pirson's } \\
\text { correlation } \\
\text { coefficient }\end{array}$ & $\mathbf{1}$ & & & \\
\cline { 2 - 6 } & p-value & & & & \\
\hline \multirow{2}{*}{ EPI2010 } & $\begin{array}{c}\text { Pirson's } \\
\text { correlation } \\
\text { coefficient }\end{array}$ & $\mathbf{0 . 3 0 4}$ & $\mathbf{1}$ & & \\
\cline { 2 - 7 } & p-value & 0.363 & & & \\
\hline
\end{tabular}




\begin{tabular}{|c|c|c|c|c|c|}
\hline \multirow{2}{*}{ SSI2010 } & $\begin{array}{c}\text { Pirson's } \\
\text { correlation } \\
\text { coefficient }\end{array}$ & $\mathbf{0 . 1 5 2}$ & $\mathbf{0 . 5 0 9}$ & $\mathbf{1}$ & \\
\cline { 2 - 6 } INOV2010 & $\begin{array}{c}\text { p-value } \\
\text { cirson's } \\
\end{array}$ & 0.665 & 0.110 & & \\
\hline & coefficient & $\mathbf{- 0 , 5 1 6}$ & $\mathbf{0 , 2 4 0}$ & $\mathbf{0 . 1 1 6}$ & $\mathbf{1}$ \\
\cline { 2 - 7 } & p-value & 0.104 & 0.477 & 0.734 & \\
\hline
\end{tabular}

Source: The author's own calculation

The multiple correlation coefficients which is 0,707 has been calculated for 2012 . This coefficient shows a substantial connection (between 0,5 and 1,0) between observed indicators. In order to get the idea concerning observed indicators interdependence, the values of the coefficient of correlation between dimensions of multifunctional rural development will be analyzed (Table 8 ). According to the Table 8 data, it can be noticed that there is a high degree of inverse matching between INOV and GVA $(-0,580)$, as well as between social and economical component - a direct (positive) connection which is 0,539 .

Table 8: Values of coefficient of correlation between dimensions of multifunctional rural development in 2012

\begin{tabular}{|c|c|c|c|c|c|}
\hline & & GVA2012 & EPI2012 & SSI2012 & INOV2012 \\
\hline \multirow[t]{2}{*}{ GVA2012 } & $\begin{array}{l}\text { Pirson's } \\
\text { correlation } \\
\text { coefficient }\end{array}$ & 1 & & & \\
\hline & p-value & & & & \\
\hline \multirow[t]{2}{*}{ EPI2012 } & $\begin{array}{l}\text { Pirson's } \\
\text { correlation } \\
\text { coefficient }\end{array}$ & 0.129 & 1 & & \\
\hline & p-value & 0.706 & & & \\
\hline \multirow[t]{2}{*}{ SSI2012 } & $\begin{array}{l}\text { Pirson's } \\
\text { correlation } \\
\text { coefficient }\end{array}$ & 0.309 & 0.539 & 1 & \\
\hline & $\mathrm{p}$-value & 0.355 & 0.087 & & \\
\hline \multirow[t]{2}{*}{ INOV2012 } & $\begin{array}{l}\text { Pirson's } \\
\text { correlation } \\
\text { coefficient }\end{array}$ & -0.580 & -0.047 & 0.122 & 1 \\
\hline & $\mathrm{p}$-value & 0.062 & 0.890 & 0.722 & \\
\hline
\end{tabular}

Source: The author's own calculation

The multiple correlation coefficient which is 0,610 has been calculated for 2014 . This coefficient shows a substantial connection (between 0,5 and 1,0) between observed indicators. In order to get the idea concerning observed indicators interdependence, 
the values of the coefficient of correlation between dimensions of multifunctional rural development will be analyzed (Table 9.). According to the Table 9 data, it can be noticed that there is a high degree of inverse matching between INOV and GVA $(-0,530)$.

Table 9: Values of coefficient of correlation between dimensions of multifunctional rural development in 2014.

\begin{tabular}{|c|c|c|c|c|c|}
\hline & & GVA2014 & EPI2014 & SSI2014 & INOV2014 \\
\hline \multirow{3}{*}{ GVA2014 } & $\begin{array}{c}\text { Pirson's } \\
\text { correlation }\end{array}$ & & & & \\
\hline & coefficient & 1 & & & \\
\hline & $\mathrm{p}$-value & & & & \\
\hline \multirow[t]{2}{*}{ EPI2014 } & $\begin{array}{l}\text { Pirson's } \\
\text { correlation } \\
\text { coefficient }\end{array}$ & 0.321 & 1 & & \\
\hline & $\mathrm{p}$-value & -0.336 & & & \\
\hline \multirow[t]{2}{*}{ SSI2014 } & $\begin{array}{c}\text { Pirson's } \\
\text { correlation } \\
\text { coefficient }\end{array}$ & -0.038 & -0.105 & 1 & \\
\hline & p-value & 0.911 & 00.758 & & \\
\hline \multirow[t]{2}{*}{ INOV2014 } & $\begin{array}{l}\text { Pirson's } \\
\text { correlation } \\
\text { coefficient }\end{array}$ & -0.530 & 0.037 & 0.171 & 1 \\
\hline & p-value & 0.094 & 0.915 & 0.615 & \\
\hline
\end{tabular}

Source: The author's own calculation

The calculation results presented in the previous tables suggest that the interdependence between observed indicators of multi-functionality is irrelevant for a practical analysis, besides the fact that multiple correlation coefficients are high. The detailed analysis of the level of partial coefficients of correlation points to this conclusion. Such researching result is expected taking into account that it refers to the countries on their way to multi-functionality. Multifunctional agrarian and rural development is characteristic for the EU countries, whereas the countries of Southeast Europe are just at the point of finding their way towards multifunctional agrarian and rural development.

\section{Conclusion}

The quantitative analysis of multi-functionality basic dimensions, through composite indicators, measures multidimensional concepts that cannot be comprised within a single indicator. Composite indicators include economic, ecological and social indicators, as well as innovative dimensions of multi-functionality. Each dimension of multi-functionality is equally important, but in some specific circumstances, some of them are given priority. The concrete analysis of composite indicators reflects the real situation in our agricultural production, besides the fact that the taken sample is 
small. The interdependence, i.e. .the power of connection between observed indicators is irrelevant for practical analysis even besides the fact that that multiple correlation coefficients are high, meaning that that Serbia is at the beginning of its multifunctional agrarian and rural development.

Multifunctional agriculture is characteristic for the European countries and it is characterized by the smallest participation of agricultural population and relatively favorable ratio of land and population.

Modernization of agriculture, as well as market influences, implies existence of the most competitive agricultural producers. Its consequence is significant participation of rural population which, after abandoning agriculture as the basic activity, find employment in non-agricultural sphere The non-agricultural activities sector is an extremely important promoter of the all economic activities in rural districts.

If the measures concerning employment in rural districts are not taken, migrations in the direction rural districts - towns are often imposed as the only "solution" .Besides all these difficulties, poor quality and difficult living conditions in the country favor migratory movements a lot.

In order to carry out .rural developing processes, great attention must be paid to capability of rural population to manage these processes and influence improvement of quality of life in their local communities.

If conditional separation of two paradigms, modernization and rural development, is accepted, Serbia must follow both ways. In order to increase competitiveness of agriculture, it is necessary to modernize it. Strategic orientation to rural development must be on the priority list.

\section{References}

European Commission, Beyond GDP. Retrieved August 12, 2015, from http://www. beyond-gdp.eu/index.html

Bogdanov, N. (2003) Ruralni razvoj-politika EU, stanje $i$ perspektive u Srbiji. Beograd: Poljoprivredni fakultet

Bogdanov, N. (2007) Mala ruralna domaćinstva u Srbiji i ruralna nepoljoprivredna ekonomija. Beograd:UNDP

Bogdanov, N. (2005.) Multifunkcionalna poljoprivreda - koncept i institucionalni okvir. In: Cvijanović, Grbić, V., (2006) Ekonomska analiza set-aside programa agrarne politike Evropske unije. Ekonomika poljoprivrede, 53(2): 279-289

Đekić, S. (2010) Agrarni menadžment. Niš: Ekonomski fakultet

Đekić, S., Vučić, S., (2006) Ruralni razvoj, zaštita okruženja i lokalni akteri. Ekonomika poljoprivrede, 53TB(13-667): 171-181

European Commission (CEC), (2006) Fact sheet: The Rural developement Policy 2007-2013, Brussels: Directorate-General for Agriculture and Rural Developement

Eurostat (2000) Manual on the economic accounts for Agricultural and Forestry. Luxembourg: Eurostat 
Zakić, Z., Stojanović, Ž., (2008) Ekonomika agrara. Beograd: Ekonomski fakultet

Janković-Milić, V., Jovanović, S., Krstić, B. (2012). Analiza ekološke dimenzije održivog razvoja zemalja Jugoistočne Evrope na osnovu EPI metodologije, Teme, No2, Univerzitet u Nišu

Krainović M., P. Tumbas, N. Ralević, M. Ševarlić, M. Milanović, (Ed) Multifunkcionalna poljoprivreda i ruralni razvoj. (14-23) Beograd

Krzanowski, W.J. (1988) Principles of multivariate analysis. Oxvord: Clarendon Press

Mihajlovic D., Ilic B., Simonovic Z., Razvoj održive ekonomije prirodnih resursa u skladu sa ekološkim zahtevima, Ekonomika, 59/4, (10-22)

Miltojević, V. (2011) Kultura kao dimenzija održivog razvoja, Teme, 35(2), 639-653

Spangenberg, J.H. (2002). Environmental space and the prism of sustainability: frameworks for indicators measuring sustainable development, Ecological Indicators, No2. Retrieved August 12, 2015, from http://www.china-sds.org/ kcxfzbg/

Sustainable Society Foundation. Retrieved August 13, 2015, from http://www. ssfindex.com/results-2014/ranking-all-countries /

Ceranić, S., Maletić, R., (2005.) Strategija razvoja malih i srednjih preduzeća u agrobiznisu Srbije, Beograd: Poljoprivredni fakultet

Cohen, J.W. (1988). Statistical power analysis for the behavioral sciences (2nd edn). Hillsdale, NJ: Lawrence Erlbaum Associates.

The World Bank, Data. Retrieved August 14, 2015, from http:/data.worldbank.org/ indicator/SP.RUR.TOTL.ZS

Mreža za podršku ruralnom razvoju. Retrieved August 15, 2015, from www. ruralinfoserbia.rs

The Global Competitiveness Report 2014-2015. Retrieved August 14, 2015, from www.weforum.org/issues/competitiveness-0/gci2012-data-platform/ 